International Journal of Engineering \& Technology, $7(4.38)(2018) 996-1000$
International Journal of Engineering \& Technology
SPC
Website: www.sciencepubco.com/index.php/IJET
Research paper

\title{
The Attitude of Non-Malays towards Malay and English Language and their Perception on Language of Choice (Malay or English) for Multi-racial Communication in Malaysia: A Study on Non-Malay Tertiary Students (UNITEN)
}

\author{
Noraziah Mohd Amin', Noor Azam Abdul Rahman² \\ ${ }^{1}$ Akademi Pengajian Bahasa, Universiti Teknologi MARA (UiTM) Pulau Pinang, Permatang Pauh, Pulau Pinang, Malaysia \\ ${ }^{2}$ Language \& Social Science Unit, College of Computer Science \& Information Technology, Universiti Tenaga Nasional, Putrajaya, \\ Malaysia. \\ *Corresponding author E-mail: tinyfunnybunny7@gmail.com
}

\begin{abstract}
The Sultan of Perak, Sultan Nazrin Muizzuddin Shah in his speech at "Majlis Anugerah Kecemerlangan Sekolah Menengah Jenis Kebangsaan Sam Tet 2017" mentioned that it is indeed awkward and ironic, if a person who is a citizen of Malaysia, with all the interests and privileges of a citizen, cannot understand, cannot speak, cannot write and cannot read in the national language of his country (Amarudin, 2017). Nevertheless, in 2006, there was $29.8 \%$ of the students of SJKCs and $47.7 \%$ of the students of SJKTs who failed to achieve the minimum level of mastery of Bahasa Malaysia (Penulisan) or Malay Language (Writing) paper in "Ujian Penilaian Sekolah Rendah" (UPSR) (Tan, 2010). Obviously, it is vital to collect some insights from non-Malays in Malaysia particularly the youth regarding their perceptions towards Malay language and English as the second widely used language in this country. Therefore, the present study was conducted with two objectives namely: 1) To investigate the attitude of non-Malay UNITEN students towards Malay and English language, and 2) To examine the perception of non-Malay UNITEN students towards using Malay and English language with Malay people. The findings showed that most of the respondents, $55(\mathrm{M}=2.37, \mathrm{SD}=1.079)$ surprisingly assigned "agreed" to item 2 ("I like using Malay language as a second language") despite admitting they did not possess good Malay language skills for their responses to item 1. This shows that the respondents seem to have mixed feelings regarding the issues of using Malay language in relation to certain aspects and this is also true for English.
\end{abstract}

Keywords: Malay language, non-Malays, English language, attitude, inter-racial communication

\section{Introduction}

"In this 21st century, the role of Malay language has changed its context from an official language, national language and language of knowledge to a language learned as a foreign language" (Alias, Rosman, Abd. Rahman \& Dewit, 2015, p. 1021). Such an idea about Malay indicates that this language is of some importance as it has many functions. Nevertheless, Mahamod and Embi (2008) argue that the negative attitude of Chinese students towards Malay language is seen as the reason why they cannot master Malay impeccably. Therefore, the present study was implemented in order to see to what the non-Malay UNITEN students think about Malay language and their preference for the language to use either Malay or English when the communication involves interracial encounter especially between a non-Malay and a Malay in Malaysia. Such information produced by this research could perhaps help enlighten Malaysians regarding language use in this country and what could be done about it.

\subsection{Problem Statement}

First, It was discovered in CLS survey in 2002 that the Chinese university students in the sequence of priority ranked English (by
$78 \%$ of the respondents), while Chinese was considered a second important language by $14 \%$ of the respondents, and as for issue of languages to learn, only $18 \%$ of the respondents revealed Malay language as a language they should learn (Helen, 2013). Although the Chinese are not the only non-Malay citizens of Malaysia that are expected to have the command of some languages especially the national language of this country, Malay, their views towards English and the second language being widely used after Malay in Malaysia and Malay per se can probably represent the perceptions of the other non-Malays as well. Hence, to discover if the current opinions of the non-Malay university students pertaining to their attitude towards Malay and English language, the present study was conducted for latest insights regarding this issue. Besides, this study also intends to discover their preferred language for multiracial communication as according to according to How, Chan and Abdullah (2015), apart from being used for official purposes with government offices, Malay language is used also for inter-racial communication with government officers if they are of different ethnic background. Therefore, the present study aims at discovering if it is the same case for university students' inter-ethnic communication. 


\subsection{Research Objectives}

The objectives of the present study had guided the direction of the study. This study intends to achieve the following objectives:

1. To investigate the attitude of non-Malay UNITEN students towards Malay and English language.

2. To examine the perception of non-Malay UNITEN students towards using Malay and English language with Malay people.

\subsection{Research Questions}

The present research is incomplete without any issue to unravel or question to answer. Thus, this study aims to seek the answers to the following research questions:

1. What is the attitude of non-Malay UNITEN students towards Malay and English language?

2. What is the perception of non-Malay UNITEN students towards using Malay and English language with Malay people?

\subsection{Significance of the Study}

This study hopes to shed light on the issue of tertiary non-Malay students' attitude towards Malay and English language. Also, it is expected that the insights obtained from this research can be another source of information and enlightenment regarding the issues discussed such as the use of Malay and English language and the preferred language for multi-racial communication in Malaysia.

\section{Literature review}

\subsection{The Position of Malay and English Language in Malaysia}

According to Laws of Malaysia, Act 32 National Language Acts $1963 / 67$, for the language to be used for official purposes, it is stated, "Save as provided in this Act and subject to the safeguards contained in Article 152(1) of the Constitution relating to any other language and the language of any other community in Malaysia the national language shall be used for official purposes" (Laws of Malaysia). With respect to the use of English as the chosen language for translation in official affairs, it is stated under Act 32, National Language Acts 1963/67, "The Yang di-Pertuan Agong may permit the continued use of the English language for such official purposes as may be deemed fit" (Law of Malaysia). In terms of order of importance, English had never been considered to as one of the Malaysian languages but it is only accepted as a second language and of secondary importance in the ranking of languages of Malaysia (Thirusanku \& Md Yunus, 2014). According to Malaysia Education Blueprint 2013-2025, one of the six primary attributes that every student should possess in order to compete globally is "bilingual proficiency" which refers to the aspiration of Malaysian government that every child in Malaysia should be "at minimum, operationally proficient in Bahasa Malaysia or Malay as the national language and language of unity, and in English as the international language of communication (Executive Summary- Malaysia Education Blueprint 2013-2025 (Preschool to Post Secondary education), n.d).Clearly, the government views Malay language as the one having a significant position and function locally as the language that unifies the people, while English language as the one having a flexible position as it can be more globally used. John (2015) states that in 2004, in Peninsular Malaysia alone, there were 41 individual languages estimated and Malay as well as English were considered the two main languages being spoken and understood by Malaysians.

\subsection{Malay and English Language Learning in Malaysia}

It is mentioned in the Malaysia Education Blueprint 2013-2025 that the Ministry of Education will commence the new initiative in transforming the students to be more proficient in English by making it compulsory for "Sijil Pelajaran Malaysia" (SPM) candidates to pass the English paper starting in 2016 in order for them to be awarded the SPM certificate (Executive Summary- Malaysia Education Blueprint 2013-2025 (Preschool to Post Secondary education), n.d). The program, "Memartabatkan Bahasa Malaysia dan Memperkukuh Bahasa Inggeris" (MBMMBI) or in English, it means, "To Uphold Bahasa Malaysia and to Strengthen the English Language" was introduced to replace PPSMI ("Pengajaran dan Pembelajaran Sains dan Matematik dalam Bahasa Inggeris") program with the objectives to: 1) uphold Malay language by using it as the medium of instruction in Science and Mathematics at national and secondary schools as well as improvement in the teaching and learning of Malay; 2) to strengthen the mastery of English by improving the English curriculum and supplying sufficient and quality teachers and materials for the improvement of the curriculum. MBMMBI introduced additional hours for learning both Malay and English in the classroom especially for SJKs. As for Malay language, for SJKs, the number of hours added for Level 1 students is from 210 minutes to 300 minutes, while 150 minutes to 240 minutes for Level 2 students. With respect to English, for national schools, the time added is from 210 minutes to 300 minutes for both Level 1 and Level 2 students, while from 60 minutes to 150 minutes for Level 1 and Level 2 students at SJKs. Ibrahim (2001) claims that the non-Malay students do not speak Malay at homes and thus, they learn the pronunciation, grammar, vocabulary, spelling and intonation formally at schools.

\subsection{The Proficiency of and Attitude towards Malay Language among Non-Malay Students in Malaysia}

With regard to Malay proficiency, a well-known linguist and literary writer of Malay, Associate Professor. Dr. Lim Swee Tim believes that the issue is not that the Chinese (including Chinese students) dislike, hate or despise Malay language but the fact is they are not proficient enough in Malay communicative language even though they managed to obtain excellent grades in Malay language subject ("Persekitaran Punca Orang Cina Gagal Kuasai Bahasa Melayu", 2014). It is reported that for general proficiency measurement with regard to ethnicities, based on 2010 SPM result, Bumiputera students performed much better on Bahasa Malaysia with $84 \%$ achieving a minimum credit at SPM as compared to $63 \%$ of Chinese students, and 57\% of Indian students. (Executive Summary- Malaysia Education Blueprint 2013-2025 (Preschool to Post Secondary education), n.d). To measure the students' command of Malay as early as 12 years old, in the analysis of the results of "Ujian Penilaian Sekolah Rendah" (UPSR) the candidates from the SJKCs and SJKTs in Melaka produced by Malacca State Department of Education, it can be seen that the students in majority had intermediate proficiency of Malay and there was also quite a large number of them who failed Malay paper (see Table 1).

Table 1: The Results of Bahasa Melayu (Pemahaman) and Bahasa Melayu (Penulisan) of the Students of National-type Chinese Schools (SJKCs) and National-type Tamil Schools (SJKTs) in Malacca in 2016 UPSR.

\begin{tabular}{|c|c|c|c|c|c|c|c|c|}
\hline \multirow[t]{2}{*}{ Paper } & \multirow{2}{*}{$\begin{array}{l}\text { Type of } \\
\text { school }\end{array}$} & \multicolumn{5}{|c|}{ Results of candidates in percentages $(\%)$ according to grades } & \multirow{2}{*}{$\begin{array}{l}\text { Total number of } \\
\text { candidates }\end{array}$} & \multirow{2}{*}{$\begin{array}{l}\text { Average grade } \\
\text { of subjects } \\
\text { (GPMP) }\end{array}$} \\
\hline & & A & B & $\mathbf{C}$ & D & $\mathbf{E}$ & & \\
\hline Bahasa Melayu & SJKC & 20.32 & 28.83 & 23.92 & 20.84 & 6.09 & 2889 & 2.64 \\
\hline
\end{tabular}




\begin{tabular}{|l|l|l|l|l|l|l|l|l|}
\hline $\begin{array}{l}\text { (Pemahaman) } \\
\begin{array}{l}\text { Bahasa Melayu } \\
\text { (Penulisan) }\end{array}\end{array}$ & SJKC & 24.75 & 20.73 & 25.93 & 17.58 & 11.01 & 2.69 \\
\hline $\begin{array}{l}\text { Bahasa Melayu } \\
\text { (Pemahaman) }\end{array}$ & SJKT & 11.94 & 28.57 & 25.37 & 26.23 & 7.89 & 469 \\
\hline $\begin{array}{l}\text { Bahasa Melayu } \\
\text { (Penulisan) }\end{array}$ & SJKT & 22.81 & 17.06 & 26.01 & 16.42 & 17.70 & 469 & 2.90 \\
\hline
\end{tabular}

Source: Malacca State Education Department.

Hamid (2005) has the idea that in learning the first language, the native speakers of this language have the motivation to master their own language. However, in mastering a second language, it depends completely on the individuals to decide if they want to be perfectly proficient in this language. Thus, it is obvious that attitude towards a language will determine a person's motivation in learning it. In a study conducted by Raju (2003), it was revealed that the Indian learners of Malay language presented a positive attitude towards Malay language and were highly motivated in learning Malay. However, it is claimed by Mahamod and Embi (2008), that the negative attitude of Chinese students towards Malay language is viewed as the factor that hinder them from mastering Malay perfectly. Their negative attitude can be related to their lack of exposure to Malay language that can be obtained through reading Malay books, watching Malay programs on television, and communicating with individuals who speak Malay.

\section{Methodology}

\subsection{Research Design}

The present study employed a descriptive and quantitative research design through the implementation of a questionnaire survey on the attitude of the non-Malay UNITEN students towards Malay and English language and the views of these students towards using either Malay or English language when communicating with Malay people.

\subsection{Participants}

The respondents were 110 undergraduate students pursuing their degree in Computer Science and Information Technology program at Universiti Tenaga Nasional (UNITEN) and those who were taking Bahasa Kebangsaan A during the implementation of the study. Bahasa Kebangsaan A is a compulsory course to be taken by local students (Malaysians) who did not get credit in Bahasa Malaysia in SPM. The other details of the respondents are presented in Table 2 .

Table 2: Demographic Profile of the Respondents

\begin{tabular}{|c|c|c|c|c|c|c|}
\hline \multicolumn{7}{|l|}{ Respondents (110) } \\
\hline \multirow{2}{*}{$\begin{array}{l}\text { Race } \\
\text { Indian }\end{array}$} & \multicolumn{3}{|c|}{ Gender } & \multicolumn{2}{|l|}{ Semester } & Age \\
\hline & 68 & Male & Female & Semester 1 & 38 & \multirow{6}{*}{$\begin{array}{l}18- \\
21\end{array}$} \\
\hline Chinese & 37 & \multirow{5}{*}{40} & \multirow{5}{*}{70} & Semester 2 & 5 & \\
\hline Kadazan Dusun & 2 & & & Semester 3 & 25 & \\
\hline $\begin{array}{ll}\text { Iban } & \text { (Dayak } \\
\text { Laut) } & \end{array}$ & 2 & & & Semester 4 & 19 & \\
\hline \multirow[t]{2}{*}{ Bajau } & \multirow[t]{2}{*}{1} & & & Semester 5 & 18 & \\
\hline & & & & Semester 6 & 5 & \\
\hline
\end{tabular}

\begin{tabular}{|l|l|l|l|l|l|}
\hline TOTAL & 110 & 110 & & 110 & \\
\hline
\end{tabular}

\subsection{Data Collection Method}

The questionnaire administered to the respondents was completed within the duration of one hour with the presence of the researchers for answering guidance and clarification regarding the items in the questionnaire should the participants needed these. A briefing pertaining to answering the questionnaire was conducted with the respondents prior to the administration of the questionnaire to make sure the respondents fully understood the nature of the study and were prepared for the data collection.

\subsection{Data Analysis}

The data obtained was computed into the Statistical Package for Social Sciences (SPSS) version 20 for quantitative analysis. Numerical data such as frequencies and percentages, mean scores and standard deviation scores were generated from this software for a more comprehensive statistical analysis of the results of the present study.

\section{Findings and analyses}

\subsection{Internal Consistency of the Pilot Test}

Table 3: Cronbach's Alpha Reliability Coefficient for the Construct Reliability Statistics: Items about the Respondents' attitude towards Malay and English language and their perception towards using Malay and English language with Malay people

$\mathrm{N}=30$

\begin{tabular}{|l|l|l|}
\hline Cronbach's Alpha & $\begin{array}{l}\text { Cronbach's Alpha Based on } \\
\text { Standardized Items }\end{array}$ & of Items \\
\hline .744 & .759 & 11 \\
\hline
\end{tabular}

A pilot test was conducted for the purpose of testing the reliability of the items in the questionnaire involving 30 respondents (15 males and 15 females). The Cronbach's alpha value, 0.744 generated by SPSS represented an acceptable and reliable value that indicated the questionnaire was reliable to be used for the study. Also, this value implies that the items in the questionnaire were basically true about the construct investigated and able to be comprehended by the respondents.

4.2. Frequency (f) Distribution (\%) for the Respondents' attitude towards Malay and English language (Research Question 1) and their perception towards using Malay and English language with Malay people (Research Question

Table 4: Independent Samples Test

\begin{tabular}{|c|c|c|c|c|c|c|c|}
\hline & \multirow{2}{*}{ : } & \multirow[t]{2}{*}{ Mean } & \multirow{2}{*}{$\begin{array}{l}\text { Std. } \\
\text { Dev }\end{array}$} & \multicolumn{2}{|c|}{ Kurtosis } & \multicolumn{2}{|c|}{ Skewness } \\
\hline & & & & \multicolumn{2}{|c|}{$\begin{array}{l}\text { Stat } \\
\text { Std. Error }\end{array}$} & Stat & $\begin{array}{l}\text { Std. } \\
\text { Error }\end{array}$ \\
\hline 1 & I think I have good Malay language skills. & 3.23 & 1.072 & .567 & .358 & -.424 & .271 \\
\hline 2 & I like using Malay language as a second language. & 2.37 & 1.079 & -.022 & .358 & .589 & .271 \\
\hline 3 & $\begin{array}{l}\text { Malay language is the medium of communication in Malaysia which must be learnt by } \\
\text { every Malaysian. }\end{array}$ & 3.91 & .683 & -.274 & .358 & -.662 & .271 \\
\hline 4 & I feel proud of myself if I can speak Malay language well. & 4.33 & .726 & .118 & .358 & -.761 & .271 \\
\hline 6 & Malay language grammar is easier to understand than English. & 4.00 & .696 & -.122 & .358 & -.640 & .271 \\
\hline
\end{tabular}




\begin{tabular}{|c|c|c|c|c|c|c|c|}
\hline 7 & I prefer using English instead of Malay language. & 3.68 & .839 & 1.889 & .358 & -1.111 & .271 \\
\hline 8 & I am more comfortable speaking Malay language than English with Malay people. & 3.85 & 1.038 & .422 & .358 & -.632 & .271 \\
\hline 9 & I think English is more universal to use for inter-racial communication in Malaysia. & 3.98 & .839 & 1.889 & .358 & $\begin{array}{l} \\
1.111\end{array}$ & .271 \\
\hline 11 & I am always being laughed at speaking Malay language with my Malay friends. & 3.84 & 692 & .300 & .358 & -.150 & .271 \\
\hline
\end{tabular}

The data shows that Skewness values range from -1.111 to .589 and Kurtosis values range -.477 to 1.889 (See Table 4 ). These values indicate that Skewness and Kurtosis are not an issue in this study. The Skewness and Kurtosis values generated are still at the recommended value of -2 to 2 (Burns \& Burns, 2008). The Skewness and kurtosis values obtained mean the respondents had given normal feedback in terms of the relationship between the items in the questionnaire and the variables investigated to form a bell curve.

Table 5: Independent Samples Test

\begin{tabular}{|c|c|c|c|c|c|c|c|c|c|c|c|}
\hline & \multirow{3}{*}{ Items } & \multicolumn{10}{|c|}{ Response options } \\
\hline & & \multicolumn{2}{|c|}{ SD } & \multicolumn{2}{|l|}{ D } & \multicolumn{2}{|l|}{$\mathbf{U}$} & \multicolumn{2}{|l|}{$\mathbf{A}$} & \multicolumn{2}{|l|}{ SA } \\
\hline & & $f$ & $\%$ & $f$ & $\%$ & $f$ & $\%$ & $f$ & $\%$ & $f$ & $\%$ \\
\hline 1 & $\begin{array}{l}\text { I think I have good Malay language } \\
\text { skills. }\end{array}$ & 18 & 16.36 & 43 & 39.1 & 0 & 0 & 27 & 24.54 & 22 & 20 \\
\hline 2 & $\begin{array}{l}\text { I like using Malay language as a } \\
\text { second language. }\end{array}$ & 1 & 0.9 & 13 & 11.81 & 0 & 0 & 55 & 50 & 41 & 37.29 \\
\hline 3 & $\begin{array}{l}\text { Malay language is the medium of } \\
\text { communication in Malaysia which } \\
\text { must be learnt by every Malaysian. }\end{array}$ & 0 & 0 & 8 & 7.27 & 0 & 0 & 74 & 67.27 & 28 & 25.46 \\
\hline 4 & $\begin{array}{l}\text { I feel proud of myself if I can speak } \\
\text { Malay language well. }\end{array}$ & 0 & 0 & 22 & 20 & 0 & 0 & 64 & 58.18 & 24 & 21.82 \\
\hline 5 & $\begin{array}{l}\text { English is not suitable to be used as } \\
\text { the language of communication } \\
\text { because it does not represent } \\
\text { Malaysian people. }\end{array}$ & 6 & 5.45 & 24 & 21.82 & 0 & 0 & 52 & 47.27 & 28 & 25.46 \\
\hline 6 & $\begin{array}{l}\text { Malay language grammar is easier to } \\
\text { understand than English. }\end{array}$ & 5 & 4.54 & 28 & 25.46 & 0 & 0 & 55 & 50 & 22 & 20 \\
\hline 7 & $\begin{array}{l}\text { I prefer using English instead of } \\
\text { Malay language. }\end{array}$ & 6 & 5.45 & 13 & 11.81 & 0 & 0 & 46 & 41.81 & 45 & 40.93 \\
\hline 8 & $\begin{array}{l}\text { I am more comfortable speaking } \\
\text { Malay language than English with } \\
\text { Malay people. }\end{array}$ & 6 & 5.45 & 44 & 40 & 0 & 0 & 47 & 42.72 & 13 & 11.83 \\
\hline 9 & $\begin{array}{l}\text { I think English is more universal to } \\
\text { use for inter-racial communication in } \\
\text { Malaysia. }\end{array}$ & 12 & 10.9 & 33 & 30 & 0 & 0 & 44 & 40 & 21 & 19.1 \\
\hline 10 & $\begin{array}{l}\text { I always feel the Malay people think } \\
\text { my Malay language is not good } \\
\text { enough if I speak in Malay with them. }\end{array}$ & 0 & 0 & 19 & 17.27 & 0 & 0 & 60 & 54.54 & 31 & 28.19 \\
\hline 11 & $\begin{array}{l}\text { I am always being laughed at speaking } \\
\text { Malay language with my Malay } \\
\text { friends. }\end{array}$ & 22 & 20 & 68 & 61.81 & 0 & 0 & 20 & 18.19 & 0 & 0 \\
\hline
\end{tabular}

Table 5 presents the findings that represent the items investigated to answer both Research Question 1 (RQ1) and Research Questions 2 (RQ2). To answer RQ1 regarding the attitude of the respondents towards Malay language, the participants as non-native speakers of this language in majority, 43 of them (39.1\%) admitted that they did not have good Malay language skills (item 1). However, most of the respondents, $55(\mathrm{M}=2.37, \mathrm{SD}=\quad 1.079)$ surprisingly agreed with item 2 ("I like using Malay language as a second language") despite admitting they did not possess good Malay language skills for their responses to item 1. A huge number of respondents, $74(67.27 \%, \mathrm{M}=3.91, \mathrm{SD}=.683)$ believed that "Malay language is the medium of communication in Malaysia which must be learnt by every Malaysian" (item 3). As for their responses to item 4 ("I feel proud of myself if I can speak Malay language well"), the respondents in majority, 64 or $58.18 \%(\mathrm{M}=$ $4.33, \mathrm{SD}=.726$ ) agreed with this item. With respect to the language that was viewed suitable to represent Malaysian identity, English was not perceived appropriate to play this role as the respondents (52 participants or $47.27 \%$ ) mostly assigned "agree" to item 5 ("English is not suitable to be used as the language of communication because it does not represent Malaysian people"). In terms of the nature of the language, half of the total number of the respondents, $55(50 \%)$ agreed that "Malay language grammar is easier to understand than English" (item 6). Most respondents, 46 of them $(\mathrm{M}=3.68, \mathrm{SD}=.839)$ admitted that English was more favorable for use compared to Malay language since they selected "agreed" as their answer to item 7 ("I prefer using English instead of Malay language").

To address RQ2 pertaining to Non-Malay and Malay communication, the respondents in majority ( 47 or $42.72 \%$ ), revealed they felt more comfortable using Malay language as compared to English when they communicated with Malay people (item 8). On the contrary, the respondents, 44 or $40 \%(\mathrm{M}=3.98, \mathrm{SD}=.839)$ mostly provided a different answer to item 9 ("I think English is more universal to use for inter-racial communication in Malaysia") when giving their opinion to a more general inter-racial interaction in Malaysia as compared to involving Malays and other races. With respect to talking to Malay people, the respondents in majority, $60(54.54, \mathrm{M}=4.23, \mathrm{SD}=.709)$ had the idea that they always felt the Malay people think their Malay language was not good enough if they spoke in Malay with them (item 10). Nevertheless, a large number of the respondents, 68 or $61.81 \%$ disagreed with the statement of item 11 ("I am always being laughed at speaking Malay language with my Malay friends") which shows they did not have any bad experience like being mocked for using Malay language with Malay people. 


\section{Conclusion and discussion}

According to Kow (2008), Malay language plays a role as a language for intra-ethnic communication and nation building. Despite this notion about Malay, surprisingly the respondents in majority still prefer English as a more universal one to be used for interracial communication in Malaysia. This clearly shows that the non-Malay students of UNITEN probably feel more comfortable communicating in English with fellow Malaysians of different races although according to Dumanig and David (2011), "Though many Malaysians speak English, not all of them are equally proficient in it" (p. 216).

Besides, the respondents of the present study seem to have a positive view towards Malay language being the medium of communication in Malaysia and that this language must be learnt by every Malaysian. This implies their sense of patriotism manifested in their belief in Malay language as the official language of Malaysia and the responsibility of every Malaysian to learn it. Nevertheless, it was discovered in a study conducted by Jalaluddin, Kasdan and Ahmad (2010), it was discovered that $15.6 \%$ of the Chinese students disagreed that Malay language was still relevant as the language that could contribute to the unification of Malaysians and this clearly proves their negative view towards this official language of Malaysia.

To conclude, the non-Malay students of UNITEN as the respondents of this study generally have mixed perceptions and feelings regarding both Malay and English language with respect to certain issues. However, they basically do not despise any of these two languages and they favor both of them when it comes to using them for certain purposes and whom they use the languages with, either Malays or other non-Malay people. Basically, the students have positive attitude towards Malay language but they do not prefer only one language over another (either Malay or English) for use in inter-racial communication.

\section{References}

[1] Alias, N., Rosman, F., Abd. Rahman, M. N., \& Dewitt, D. (2015) The potential of video game in Malay language learning for foreign students in a public higher education institution. Procedia - Social and Behavioral Sciences. Elsevier Ltd. p.1021

[2] Raju, C. 2003. Sikap dan motivasi pelajar India dalam pembelajaran bahasa Melayu sebagai bahasa kedua. Kertas Projek Sarjana Pendidikan. Fakulti Bahasa Melayu, Universiti Kebangsaan Malaysia, Bangi.

[3] Tan, Y. S. (2010). Isu bahasa, Etnik dan pembinaan negara bangsa dalam sistem pendidikan Malaysia. Pulau Pinang: Penerbit USM.

[4] Laws of Malaysia (Reprint), Incorporating all amendments up to 1 January 2006. Published by the Commissioner of Law Revision, Malaysia under the Authority of the Revision of Laws Act 1968 in collaboration with Malayan Law Journal Sdn Bhd and Percetakan Nasional Malaysia Bhd, 2006.

[5] Shamsul Kamal Amarudin, (23 Oktober 2017). "Pelajar sekolah vernakular wajib fasih BM"- Sultan Nazrin. BH Online | New Straits Times Press (M) Berhad.

[6] Thirusanku, J., \& Md Yunus, M. (2014).Status of English in Malaysia. Asian Social Science; Vol. 10, No. 14, Canadian Center of Science and Education.

[7] Persekitaran Punca Orang Cina Gagal Kuasai Bahasa Melayu. (2014). Available http://www.utusan.com.my/berita/nasional/persekitaran-puncaorang-cina-gagal-kuasai-bahasa-melayu-1.26112\#ixzz54y3zK0Wn

[8] Dumanig, F.P., \& David, M.K. (2011). Language use and bilingual consumers: an analysis of print advertisements in multilingual Malaysia. Bridging the Gap of Cross-cultural Communication. Kuala Lumpur: University Malaya. p.216

[9] Executive Summary- Malaysia Education Blueprint 2013-2025 (Preschool to Post Secondary education), n.d. Available at:

[10] Hamid, Z. (2005). Penilaian pengajaran dan pembelajaran Bahasa Melayu. Kuala Lumpur: Dewan Bahasa dan Pustaka.

[11] Helen, T. M. H. (2013). Language, Identity and Mobility: Perspective of Malaysian Chinese Youth. Malaysian Journal of Chinese Studies. Kuala Lumpur: Universiti Malaya.
[12] Ibrahim, K. (2001). Bahasa Melayu dalam pendidikan negara bangsa. Prosiding Konvensyen Bahasa Kebangsaan. Kuala Lumpur: Dewan Bahasa dan Pustaka.

[13] Mahamod, Z., \& Embi, M. A. (2008). Sikap pelajar Cina terhadap pembelajaran bahasa Melayu sebagai bahasa kedua. Psikologi dalam pengajaran dan pembelajaran bahasa Melayu. Shah Alam: Karisma Publications Sdn. Bhd.

[14] Jalaluddin, N. H., Kasdan, J., \& Ahmad, Z. (2010). Sosiokognitif pelajar remaja terhadap bahasa Melayu. GEMA Online Journal of Language Studies 10(3): 67-87.

[15] John, D. A. F. (2015). Language choice and ideology: Examining the use of the Malay language in English newspaper advertisements in Malaysia. Language \& Communication. Elsevier Ltd. p.88

[16] Kow, K.Y.C., (2008). Bilingualism, culture and identity. BOCA The South Florida Journal of Lingustics 1 (2). p.113 